VYTAUTAS TUMĖNAS

Lietuvos istorijos institutas

Lithuanian Institute of History

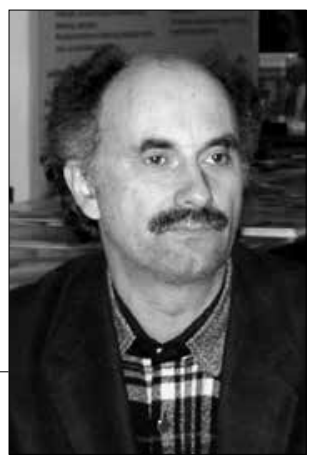

\title{
LIETUVIŲ KALVIŠKŲJŲ "SAULUČIŲ“ SIMBOLIAI SKIRTYBIŲ IR BENDRYBIŲ PRIEŠPRIEŠOS LAUKE
}

\author{
A Sun-like Cross Symbols of the Lithuanian Smithery \\ in the Field of Confrontation of Cultural Differences \\ and Commonalities
}

\begin{abstract}
SUMMARY
The article analyzes the tradition of Lithuanian iron minted sun-like crosses, as the visual sign and instrument of socio-cultural power. It examines how communities and state authorities could have seen the unifying and dividing codes at the same time in the same signs. The personal stories of blacksmiths reveals how the iron sun-like crosses were used in various ways: the construction of national identity, the preservation of cultural peculiarity or initiating the conflicting intercultural communication, and the isolation and resistance to soviet cultural colonisation. The investigation uncovers how another non-conflicting and more acceptable interpretation for the soviet ideology was attributed to the smithed sun-like crosses. This interpretation came about through communication with the government institutions. Through a precise semiotic, historical and comparative analysis, the complicated and international aspects of their meaning, origin and migration are disclosed. The origins of the serpent-like rays may be traced not only from pre-Christian imaginery, they are found in the Gothic/Renaissance art motifs of Northern Italy. By the preservation of sun-like crosses the folk art tradition during the soviet period made their Christian semantics viable at the same time.
\end{abstract}

\section{SANTRAUKA}

I lietuvių kalviškųjų saulučių-kryžių tradiciją žvelgiama kaip į vizualų ženklą, tampantị socialinės-kultūrinės galios instrumentu. Nagrinėjama, kaip bendruomenės jame gali matyti ir skirtingus, ir panašius kodus, suteikti jam ir skiriančias, ir vienijančias interpretacijas. Pasitelkus kalvių pasakojimus, aiškinamasi, kaip kalviškųjų saulučių ženklai buvo pasitelkiami kuriant tautinę tapatybę, saugant kultūrinę savastį arba kurs- 
tant tarpkultūrinį konfliktiškumą, plètojant atsiribojimą ir rezistenciją prieš sovietinę kultūrinę kolonizaciją; kaip, bendraujant su valdžios institucijomis, jiems būdavo priskiriama kitokia kompromisiškai nekonfliktinè interpretacija, priimtina sovietinei ideologijai. Taikant semiologinę, istorinę bei komparatyvinę vizualių simbolių analizę, atveriami sudètingesni, tarptautiškesni tiriamų ženklų sanklodos, reikšmės, kilmės ir migracijos aspektai. Banguotų spindulių saulučių motyvas kildintinas ne tik iš ikikrikščionišku vaizdinių, bet ir iš Šiaurės Italijos gotikos/renesanso dailès. Išsaugojus sovietmečiu kalviškų saulučių tradiciją kaip liaudies kultūros reiškinị, drauge išliko ir jų krikščioniškoji semantika.

\section{IVADAS}

I vizualius ženklus galima žvelgti kaip i̇ ideologijos elementą. Lietuvišku kalviškujju saulučių-kryžių tradicija XX a. viduryje, praradus Nepriklausomybę, tapo ideologiškai jautriu, konfliktiškumą skatinančiu reiškiniu. Šis vizualiosios etninès kultūros reiškinys ju puoselètojų entuziastu buvo suvokiamas kaip pranešimas apie savituma, išskirtinumą ar unikalumą. Šie ženklai buvo pasitelkiami kuriant, išsaugant tautinę, religinę tapatybę ar kurstant tarpkultūrinị konfliktiškuma, plètojant kultūrinį atsiribojimą ir rezistenciją. Todèl tie patys ženklai už juos puoselëjančių bendruomenių ribų igijo kitokią, atitinkamai priešišką reikšmę. Tačiau jie gali būti perskaitomi ir universaliau (kaip potencialūs humaniškos bendrystès kūrimo ịrankiai), ir objektyviau. Tai neretai skiriasi nuo vidinio emic bendruomenių požiūrio, kuris yra socialiai, kultūriškai, religiškai ir politiškai ittrauktas, suinteresuotas ir dažniausiai grindžiamas išskirtinumo, skirtybès paradigma.

Iprasta, jog vizualieji simboliai itin glaudžiai siejami su kultūrine tradicija, paveldu. Etninès kultūros paveldas dažniausiai aiškinamas kaip žinija, kartu kaip kultūrinè produkcija bei kultūrinès politikos versmè, šaltinis. Paveldas neretai susiejamas su vietinès autonomijos ideologija. Kadangi paveldo žiniją apibrèžia tam tikra socialinè kultūrinè aplinka, terpé - vadinasi, ją smarkiai lemia ir laikotarpis. Todèl jos reikšmė gali būti suvokiama ir kaip tekstas, kuris gali būti ilgainiui kitaip perskaitomas pakitus aplinkybėms, terpei. Vadinasi, tokia žinija taip pat gali tapti priešpriešų ir varžybu lauku, kuris nèra pastovus ir nekintantis ${ }^{1}$. Tokiu būdu tapatybè, pasak Zygmunto Baumano, susijusi su „laiko jausmais, laiko pojūčiais" ir atavistinèmis baimèmis, kas nèra „,saugi viso gyvenimo garantija“, todèl dèl jos nuolatos ginčijamasi ir pervardijama ${ }^{2}$. Sekant M. Guibernau galima teigti, jog tapatybè nurodo kelius, kuriais praeitis ir paveldas, kalba, religija, etniškumas, nacionalizmas yra pasitelkiami kurti įtraukimo ir išskirtinumo naratyva, kuris apibrèžia bendruomenes ir kelius, kuriais nusakoma ju specifika, ypatingumas ir skirtingybès ${ }^{3}$. Kitoniškumo atpažinimas, pripažinimas gali padèti sustiprinti savasti - tapatybę, bet taip pat gali vesti i nepasitikèjima, vengimą ir išskyrima/atskyrimą ${ }^{4}$.

Kokiomis aplinkybėmis susiformavo ir plètojosi lietuvių kalviškoji kryždirbyste, koks jos santykis su tradicijos ir tapatybės išsaugojimo bei rezistencijos paradigmomis, koks buvo sovietinės valdžios atstovu požiūris ị jos simboliką - i 
šiuos klausimus atsakyti 2016-2017 m. kalbinau tikslingai pasirinktus žymiausius Lietuvos tautodailininkus kalvius.
Jų atsakymai yra artimi subjektyviems pasakojamosios istorijos ar folkloriniams naratyvams.

\section{KALVIŠKŲJŲ „SAULUČIŲ“ TRADICIJOS LIKIMAS SOVIETMEČIU}

Lietuvių tradicinès kalvystės geležinių „saulučių" simbolika daugialypè, ji turi įvairių reikšmių - tiek vietinių, tiek tarptautinių istorinių sąsajų ir semantikos kontekstų. Šis vizualus simbolis menininkų diskursuose dažniau siejamas su tautinio savitumo idejja bei ikikrikščioniška estetika, nors drauge turi akivaizdžiu krikščioniškosios tradicijos požymių.

Senają Lietuvos medinių ir geležiniu kryžių-saulučiu simboliką yra nagrinèję P. Galaunè ${ }^{5}$, A. Rūkštelèं ${ }^{6}$ J. Perkovskis ${ }^{7}$, M. Gimbutiené ${ }^{8}$, A. Mažiulis ${ }^{9}$, Ž. Mikšys ${ }^{10}$, J. Zabulytè ${ }^{11}$ ir kt. Tačiau šios simbolikos transformacijos šiuolaikinejje tautodailèje i̇dėmiau dar nèra tyrinètos.

Šio reiškinio likimo XX a. analizè padeda atsekti geležinių saulučių vaizdinio mentalinio įsimbolinimo kelią ị lietuviu šiuolaikinių tautinių simbolių grupę. Tai vyko siekiant universaliems, globaliems krikščioniškiems simboliams suteikti tautini atspalvị, grisstą ikikrikščioniško dvasingumo "tradiciju archeologija“. Be to, stipresnis poreikis plètoti tautinius, vietinius vizualius simbolius buvo gristas rezistencija sovietizacijai. Kita vertus, ieškoti nauju krikščioniškos simbolikos interpretacijos būdų vertè ir antireliginès, ateistinès sovietinio režimo nuostatos - persekiojimai ir draudimai tautodailininkams puoselèti krikščionišką kryžių kūrybos tradiciją. Tautodailininku kūrybinè diplomatija buvo tokia išradinga, kad pavyko rasti gyvybingą būdą, kaip, atsiribojus nuo religinio krikščioniškojo turinio, geležiniu saulučiu žinia kalbèti „sovietiniuose rèmuose“ apie estetinę liaudies meno, jo mitopoetiniu vaizdiniu tradiciją. Moderniai interpretuoti kryžiu simboliką tautodailininkus kalvius paskatino mokslininkų darbai, kuriuose nagrinèjami senosios liaudies dailès archajiški ikikrikščioniški ir krikščioniški elementai. Idejų raidos genezė atskleidžia, kad lemtingas ir ikvepiantis „pagoniškas“ interpretacijas šiuolaikinèje tautodailèje tapo etnologès, archeologès Marijos Gimbutienès komparatyvinis mitologinis-etnodailètyrinis veikalas apie lietuvių liaudies meno simboliką ${ }^{12}$, kuris Lietuvoje buvo slapta išverstas ir entuziastingai skleidžiamas bei skaitomas. Drauge mentaliteto "užkulisiuose" gyvavo samprata, kad dabarties tautodailininku saulutès - tai krikščioniškosios Lietuvos dailès tradicijos šiuolaikinè adaptacija. Kryždirbystės „saulučių“ vaizdinys kaip lietuviu tapatybės ženklas tapo itin artimas menininku bendruomenei - jis plito i juvelyrika, profesionalią vaizduojamająa dailę.

Kryždirbystè sovietmečiu buvo konspiratyvi meninè veikla, liudijanti kultūrinę takoskyrą tarp "mūsų" tradicijos ir ,jü sovietizacijos. Tačiau kryždirbystès draudimas nebuvo visiškai griežtas, nes pasireikšdavo ir subjektyvus valdžios atstovu požiūris, kartais liudijantis užslėptą kultūrinès rezistencijos palaikymą. 


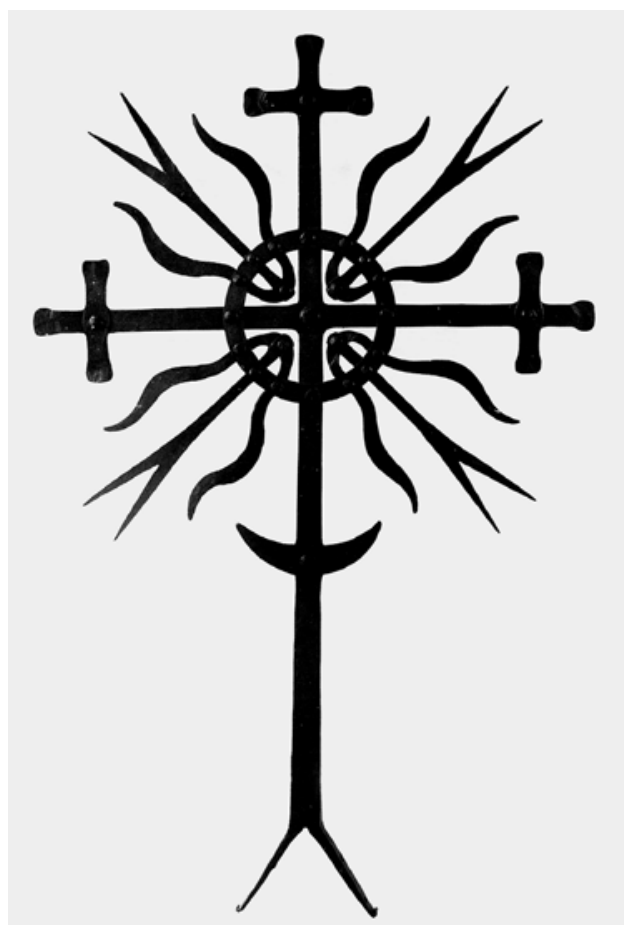

1 pav. V. Jarutis. Kalviškas kryžius. XX a. 9 deš.

Antai kalvis Česlovas Pečetauskas (g. 1946) prisimena, kaip sovietmečio pradžioje kryždirbystė buvo nustumta i oficialios kultūros užribì, slaptos ekonominès amatų veiklos, religinès rezistencijos sriti:

Nedarydavom parodinių kryžių. Daugiau geležinius kryžius privačiai užsakydavo tyliai ramiai paminklą pastatydavo kapinèse, o akmentašys ar mūrininkas pritaisydavo kryželi prie akmens ar mūrinio paminklo. Valdžia ị kapines nekreipdavo dèmesio, santvarka i tai per daug nesikišo. Kapinès toks šventas dalykas. Būtų per žiauru, jeigu būtų pradeję niekinti kapus ar kitaip draskyti <...>. Sovietmečiu krikštydavo ir vaikus, ir pirma Komunija būdavo. Daroma slaptai. Mane naktį vedè i bažnyčią. Kad ryte ten mišių metu nelegaliai užkulisiuose prieit pirmą Komuniją <..>. Suvaržymų daryti religinius dirbinius sovietiniais laikais nebuvo labai didelių, nebent kituose regionuose. Aš gimęs, augęs Dotnuvos krašte. Mūsų pusejj nebuvo taip, kad tu pastatei, o jie akiplèšiškai nuverstų. Nepasakyčiau, kad sovietinè valdžia drausdavo, bausdavo, draskydavo, sudaužydavo. Kažkaip, matyt, valdžioj irgi žmonės buvo... Kai tokia santvarka - nori, nenori... Kitas, sukandęs dantis kentèjo tą santvarką - neturëjo kur dètis. Jeigu tu nebūsi komunistas - tai nebūsi kolūkio pirmininkas, o jeigu tu dar pasakysi, kad nenori - tai paklaus: „kodèl nenori? - esi liaudies priešas!“

Vytautas Jarutis (1936-2017) (1 pav.) apibūdino kolonizacinę ideologinę terpę, kurioje formavosi kryždirbių estetinès nuostatos, bei kokie buvo karjeros apribojimai už religinès dailès puoselejimą:

Sovietmečiu kryžius kapinėse darydavom individualiai. Niekas ten per daug nesikabindavo, bet perspèdavo. Bet viešose vietose - jau ne. Mes visi su kunigais bendravom. Ir I. Užkurnys, ir daug kitų medžio drožejų slapta darè bažnyčiom ir dievuliukus, ir kryžius. Bet niekas tų darbų nesiviešino. Ir kapinėse darėm. Ten niekas nevažiuos tau ieškot kur. Visur buvo pilna kryžiu tais laikais <...>. Atvažiuoja žmogus, sako: „Man rekomendavo, kad galiu su tavim atvirai kalbèt... Mano mama mirdama prašè, kad aš padaryčiau jos kapam kryžių, kad prie jos būtų paminklas kryžius. Aš dirbu ministerijoj, rimtose pareigose. Jeigu aš padarysiu mane pašalins iš darbo. Bet man pasakè, kad „gali i tą žmogu kreiptis; pasakyk vietą - jis nuvažiuos, pažiūrès ir padarys, ir niekas nežinos“. Tai mes taip ir susitarèm. Aukštaitijoj aš padariau tą kryžiu, jo giminè tarpininkavo... Ne visi buvo ten ideologiniai tie darbuotojai valdžioje. Mes žinojom, ką mes darom, ką mes galim, ko negalim. Ir darèm tikrai šventus darbus. Tiktai tas, kas nežino to laikotarpio, gali 
aiškinti, kad ten sovietine i̇taka <...>. Tie, kurie sako, kad mes kūrèm sovietini meną, perlenkia lazdą. Ta propaguojama ideologija buvo kita, nei mūsų dvasinis pasaulis. Mes parodose negalèdavom rodyti kryžių, bet kapinėse tau nieks neuždraus. Aš dirbau Merkinès bažnyčiai, kada mane isskundè Saugumui. Tada mane nusprende pašalint iš Liaudies meno draugijos (nes tie, kurie darẻ bažnyčiose, ar dievukus, tai ne vienas buvo pašalintas iš jos. Nenubausdavo, tik uždarydavo kelią i viešą kūrybą. Netapęs LDM nariu, aš jau nebūčiau galëjęs dalyvaut parodose). Su rašytoju V. P. mes labai gražiai bendravom, tai jis atvažiavo tuo reikalu žiūrèti. Atsivežè ị Merkinę prie bažnyčios, sako: „einam, parodyk, ką tu čia pridarei“. $\mathrm{O}$ aš ten tik pagrindinių durų visus apkaustus padariau ir zakristijos spyną kalvišką labai sudètingą... Viršuj buvo niša - aš buvau sutaręs su klebonu, kad padarysiu kryžių. Bet dar nebuvau pradejjęs. Tai ir išgelbèjo. V. P. apžiūrèjo, apžiūrèjo, sako: „O kur kryžius?“ O buvo paskųsta, kad ir kryžius ten darau. Sakau: „Vytautai, dar nespejjau padaryt kryžiaus." V. pasilenkè man per petị ir sako: „Tu neerzink tų durnių, tu kentèsi. Nedaryk to kryžiaus." Pažiūrèkit, kokia žmogaus dvasia - ką jis man pasakè. Ir dar sako: „Saugokis to žmogaus nes jis tave įskunde..“ Ir dar: „Pirmininkas tave šalins iš Liaudies meno draugijos." Kada ịsikišo V. P., tai man Pirmininkas sako: „Džiaukis, kad tu turi toki gerą drauga, kuris tave išgelbejjo.“ Tai aš jam atsakiau: „Ką tu šneki? Kultūros ministerija davè leidimą restauraciniams darbams bažnyčiai.

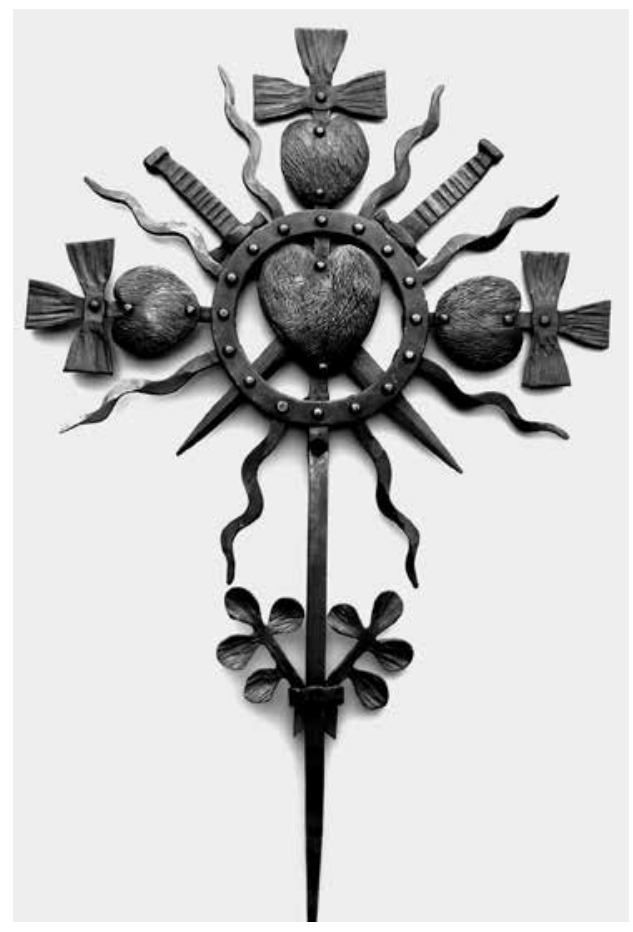

2 pav. S. Špūkas. Kalviškas kryžius. XXI a. pr.

Tai Kultūros ministerija sovietam priklauso ar kažkokiai kitai valstybei? Tai tas tik mik, mik. Sakau: „Pažiūrèkit, gavo leidimą restauracijai ir mane pasikvietè restauraciniams darbams..."

Kalvis Stanislovas Špūkas (g. 1940) (2 pav.) apie tradicinių kryžių likimą pokariu prisimena: „Iš Norvydžių eidavom ì Šiluvą keliu per pušyną, daug buvo labai koplytėlių gražių pristatyta. Ir "saulutès” ten būdavo, kažkas kaldavo. Paskui stribai jas iššaudè, išdaužè ir nebeliko..."

\section{"SAULUČIŲ“ KALVYSTĖS TAPSMAS IR AIŠKINIMAS MODERNYBĖJE}

Sovietmečiu gyvają kalvystès tradiciją palietè modernizacija, tačiau kalviai dar labiau susidomèjo ir kalvystès isto- rinėmis technologijomis bei formomis studijuodami knygas ir muziejų eksponatus. Tautodailès specialistams pavyko 


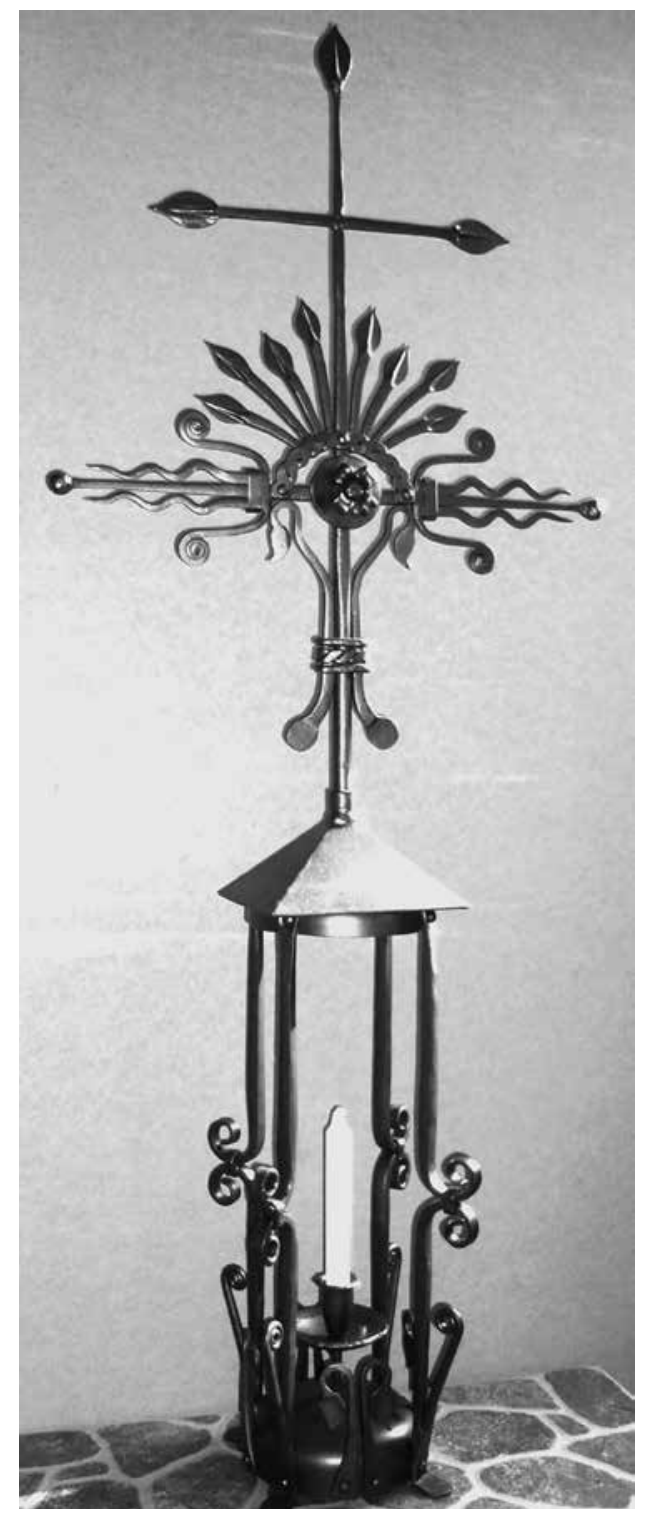

3 pav. Č. Pečetauskas. Kalviškas kryžius. XX a. pab.

itraukti metalo kryždirbystę i naujujuc tautodailès skulptūrų-paminklų puošyba, kviesti jos kūrèjus i parodas. Kita vertus, kalvystė rutuliojosi ir tradicinejje terpejje per tėvų, draugu ir pažistamuju itaką ir būsimų kalvių tiesioginị sąlytị su kraštovaizdžio paveldu bei vietiniais religiniais papročiais.
Č. Pečetauskas (3 pav.) tradiciją perèmė iš savo giminių ir kaimynų:

Aš nuo aštuoniasdešimtųjų metų pradèjau kalviauti. Pradžioj tai buvo hobis. Dariau žvakides, namų apyvokos daiktus, detales interjerui. Kaip Blaivybės draugijos narys skaičiau mažuose miesteliuose paskaitèles apie blaivybę ir drauge darydavau savo darbų parodèles - ten ir savo kryžius rodydavau.

Mano senelis buvo dvaro kalvis, o tèvas buvo ir dvaro, ir savarankiškas. Kalviškų darbų dvare buvo visokių: reikdavo ir kaimo bažnytèlę papuošti, ir varpinę... Vis kryželiu visur reikèjo.

Susidomèti metalo kryždirbyste ji paskatino ir kraštiečio vienuolio kapucino Tėvo Stanislovo (A. M. Dobrovolskio, 1918-2005) kūrybinè veikla. Kalvio liudijimu, Tèvas Stanislovas buvo vienas aktyviausių kryžių-saulučiu propaguotojų ir kūrèjų. Jis kalè kryžius saulutes interjerams, dovanojo jas mylimiems žmonėms. I jo kryždirbystės reikšmę kultūros raidai atkreipè dèmesị ir V. Milius, ragindamas, kad laikas susidomèti Tėvo Stanislovo kūryba, juk jo sukurti kryžiai yra paplitę tiek eksterjeruose, tiek interjeruose ${ }^{13}$.

Č. Pečetauskas savo amato pradžią sieja su alternatyvia bažnyčios galia, o kūrybingumą - su Lietuvos tautodailininkų sąungos veikla:

Meniški tradiciniai kryžiai man parūpo drauge su "Aukso vainiko“ konkursais, taip pat su V. Jezersko pradètais kalviškos kryždirbystės konkursais. Juose ir tapau Lietuvos kalvių kalviu. Pirmos parodos vyko 1982, 1985 metais. Aš eksponavau ir kryžius. Bet jų neišryškindavau - dariau kaip saulutes su puošybinèm gèle- 
lèm. Nedarydavau aklai tik tam, kad pasidèti, parodoj eksponuoti. Visi jie „iškeliaudavo": užsakymai būdavo i̇ kapines, o ypač i bažnyčią. İ bažnyčią valdžia irgi nelysdavo per daug. Nebuvo bažnyčios uždarytos, bet buvo suvaržytos. Atributika visa sakralinè vis tiek buvo. Drožèjai ir Marijas droždavo, ir Rūpintojèlius. O kiek daug jų buvo...

Vladas Kuzinas (g. 1952) kryždirbystëje iškilo itin nuodugniai studijuodamas paveldą muziejuose, konsultuodamasis su mokslininkais:

Aš atèjau i i kalvystę 1984 m. I Lietuvos tautodailininkų sajungą mane prièmè po dvejų metų. Tada ir pradejjau saulutes, kryžius daryt. Kaimo kalviai darydavo paprastesnes. O man patiko klasikinis stilius. Tais laikais reikejjo daug pastangu, kad reikiamą knygą surast. Šios žinios sunkiai prieinamos buvo. Visi jauni žmonės mano, kad jie viską moka ir žino. Bejgant laikui, supranti, kad nelabai daug ko žinai ir moki, reikia mokytis, domètis. Giliau kalvystės tradiciją pažinau vẻliau, kai nuvažiavau 1989 m. i̇ Rygą. Ten profesorius Antein Aleksis (knygos „Damaskinis plienas Baltijos šalyse" autorius) man daug papasakojo apie istorinę kalvystę ir atspausdino rašta, skirtą Lietuvos nacionalinio muziejaus direktoriui: kad yra toks jaunas kalvis, kuris viską moka, viską žino; jūs padèkit jam susipažint su fondais ir paglobokit. Kai man suteikè galimybę dirbt fonduose, supratau, kad visiškai nieko aš nežinau... Kai važiavo i i Švediją archeologijos, istorijos vadovai, tai jiems reikèjo restauruoti tu saulučių kolekciją. Paskui kilo mintis sau pasidaryt saulučiu (kopijų) kolekciją ant sienos. Prasidejjo savų staklių gamyba, istorijos klausimai, saulučiu, kalaviju ir ju makščiu kalyba. Kai pradejau mokytis ir domètis, paaiškejjo, kad ne taip viskas paprasta ir literatūros nèra daug. Iki šiol Č. Kontrimo knyga geriausia - klasifikuo-

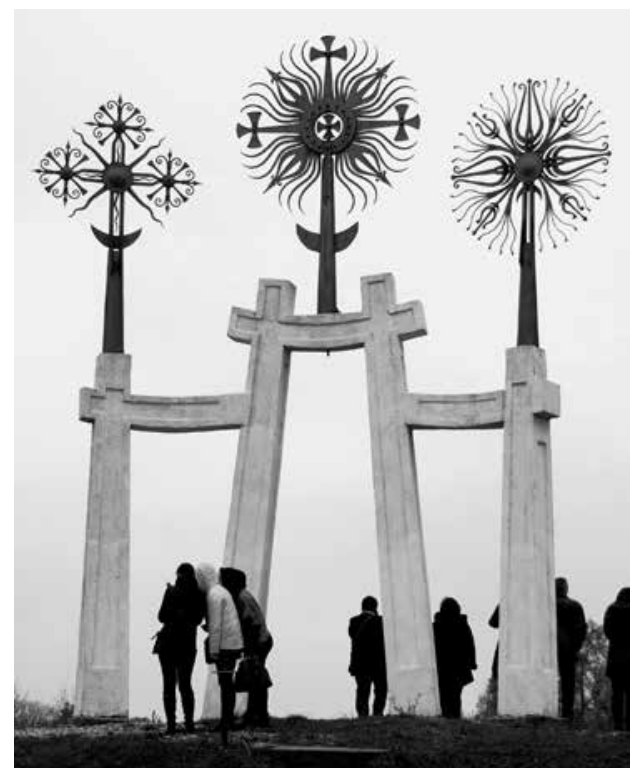

4 pav. V. Kuzinas. Kalviški kryžiai. V. Cikana. Vartai. 2009 m., Lukšiai, Šakių r.

ta pagal rajonus ir t. t. Šiuolaikiniai kalviai meistrai visokiu ten vielyčiu privirina, privirina. Man nepatinka tokie dalykai... Muziejų fonduose dirbdavau. Man suteikè galimybę, aš nusipiešiau 200 pavyzdžiu kaimo kalvių saulučių. Kitiems taip neleisdavo, bet man, kadangi aš ten dirbau istorijos ir archeologijos skyriuje, leido. Tai pasiguldau ant popieriaus kryžiu - ir pieštuku siluetą apsivedu, užsirašau numeri eksponato. Rulonai tokių buvo... Pradejjau daryti saulutes ir ant paminklų kapinèms. Tada man pasirodè idomu padaryti parodai kolekciją saulučių visiškai ne už pinigus. Nes yra daug tokių, kurias aš pats sugalvojau, bet yra ir daug tokių saulučiu, kur aš nieko nekūriau - aš paimu ir atkartoju originalą.

V. Kuzino kūrybą ikvėpe ir Sajūdžio iškeltos idejjos. Jeigu nebūtų Vilniuje atstatyti po susprogdinimo Trys Kryžiai jam nebūtų gimusi mintis sukurti 8 metrų aukščio trijų kryžių-saulučių paminklą (Lukšiai, 2009 m.) (4 pav.). 


\section{Literatūra ir nuorodos}

${ }^{1}$ Brian Graham, Peter Howard, Heritage and Identity. The Ashgate Research Companion to Heritage and Identity. Brian Graham, Peter Howard (eds.). Hampshire, Burlington: Ashgate Publishing Limited, 2008, p. 2-5; Iain J. M. Robertson, Heritage from Below: Class, Social Protest and Resistane. Ten pat, p. 144-147.

2 Zygmunt Bauman, Identity: Conversations with Benedetto Wecchi. Cambridge: Polity Press, 2004, p. 11.

3 Monsterrat Guibernau, Nationalisms: the NationState and Nationalism in Twentieth Century, Cambridge: Polity Press, 1996.

${ }^{4}$ B. Graham, P. Howard, Heritage and Identity, p. 11.

${ }^{5}$ Paulius Galaunè, Lietuviu liaudies menas. Kaunas: L.U. Humanitarinių mokslų fakulteto leidinys, 1930.

${ }^{6}$ Antanas Rūkštelè, Lietuvių kryžiai. Jų kilmès aiškinimai ir trūkumai, Draugas (2 d.), 195703 03, p. 1-2, 5 .

7 Juzefas Perkovskis, Žemaičiu liaudies meno ornamentas: forma ir simbolika. Vilnius: Vilniaus dailès akademijos leidykla,1999, p. 26-30.
8 Maria Gimbutas, Ancient Symbolism in Lithuanian Folk Art. Memoirs of the American Folklore Society. Vol. 49. Philadelphia: American Folklore Society, 1958.

9 Antanas Mažiulis, Lietuviškasis kryžius ir jo kilmè, Aidai 2, 1951, p. 60-70.

10 Žibuntas Mikšys, Saule ir žaliuojantis medis religinio meno šviesoje, Aidai 3, 1959, p. 112122.

11 Jolanta Zabulytè, Saulès kulto apraiškos armènų ir lietuvių kryžiuose, Eidos: filosofinès antropologijos, hermeneutikos ir orientalistikos žurnalas, 2004. [http://www.litlogos.eu/eidos/research/ zabulite.html [žiūrèta 201707 25]; J. Zabulytè, Saulès motyvai XIX a. pabaigos-XX a. pradžios medinių kryžių dekore: forma, kilmè, reikšmès interpretacijos, Liaudies kultūra 3 (96), 2004, p. 30-47.

12 M. Gimbutas, Ancient Symbolism.

13 Vacys Milius, Išeivijos lietuvių kryžiu tyrinèjimai, Lietuviu kataliku mokslo akademijos metraštis. Vilnius: Lietuvių katalikų mokslo akademija, (t. 21), 2002, p. 82.

B. d. 